\title{
High mortality of Pacific oysters in a cold winter in the North-Frisian Wadden Sea
}

\author{
Heike Büttger · Georg Nehls · Sophia Witte
}

Received: 22 March 2011/Accepted: 12 August 2011/Published online: 27 August 2011

(C) Springer-Verlag and AWI 2011

\begin{abstract}
Mortality of introduced Pacific oysters (Crassostrea gigas) was studied in the northern Wadden Sea in response to an ice winter. After a decade of mild winters, in January and February 2010, the first severe winter occurred since the Pacific oysters became dominant on former intertidal blue mussel (Mytilus edulis) beds in the NorthFrisian Wadden Sea. After the ice winter, mortality of Pacific oysters on densely populated beds in the List tidal basin reached about $90 \%$, indicating much higher losses in comparison to former mild winters. At lower densities between the islands of Amrum and Föhr, oysters were less or even not affected. Although Pacific oysters are assumed to be very tolerant to frost, the duration of cold water- and air temperatures accompanied by mechanical stress of the ice burden might have caused the high mortality in the winter 2009/2010 in formerly dense beds.
\end{abstract}

Keywords Crassostrea gigas · Ice winter · Mortality · Wadden Sea

\section{Introduction}

Winter temperatures are one of the most important variables structuring the benthic communities of the Wadden Sea. As a variety of native species are very sensitive to low temperatures, cold winters with ice covering the tidal flats may lead to mass mortality of some species, but give others an advantage by reducing competition or predation rates (Beukema 1992; Beukema and Dekker 2005; Strasser and Günther 2001). Species abundance and community structure

H. Büttger $(\varangle) \cdot$ G. Nehls $\cdot$ S. Witte

BioConsult SH, Brinckmannstr. 31, 25813 Husum, Germany

e-mail: h.buettger@bioconsult-sh.de vary markedly in response to winter temperatures. Thus, a period of mild winters may give an early insight into the long-term consequences of climate change (Beukema 1992).

The Pacific oyster (Crassostrea gigas) has been introduced to various places within the Wadden Sea (Nehls and Büttger 2007). It has extended its range within the Wadden Sea during the last decade by colonising former intertidal blue mussel (Mytilus edulis) beds. The Pacific oyster is described as being very tolerant to low winter temperatures, as it can stand frost for long periods (Diederich 2006). Pacific oysters occur generally in regions with a lower SST (sea surface temperature) of between -1.9 and $19.8^{\circ} \mathrm{C}$ and lower air temperatures of between $-23^{\circ} \mathrm{C}$ and $14^{\circ} \mathrm{C}$ (Carrasco and Barón 2010).

Cold winters in the Wadden Sea are, however, not sufficiently described by low temperatures alone, as ice cover on the tidal flats and consequent movements of the ice caused by the tides leads to strong mechanical impacts on all intertidal species. The native blue mussel is reported to be very tolerant to low temperatures, but intertidal beds of the species might be completely removed by moving ice on the tidal flats (Nehls et al. 2009).

In the North-Frisian Wadden Sea, the most recent severe winter before 2009/2010 occurred in 1996/1997 with more than 70 days of ice coverage (BSH 2010a). Since then, winters have been comparatively mild, with only a few days with ice occurring in 2003, 2006 and 2009. Thus, the impact of cold winters on survival of Pacific oysters could not be studied after its successful colonisation of the tidal flats of the North-Frisian Wadden Sea.

During the winter 2009/2010, a thick layer of ice was formed on the intertidal flats, with 49 days of ice coverage near the island of Amrum and 56 days ice coverage in the inner parts of the North-Frisian Wadden Sea near Husum. Water temperature dropped to around $0^{\circ} \mathrm{C}$ (BSH 2010b). 
These specific conditions gave us the opportunity to investigate the mortality of introduced Pacific oysters in the North-Frisian Wadden Sea after a cold winter and to compare it with preceding mild winters.

\section{Methods}

This paper focuses on data from the List tidal basin of the Sylt-Rømø Bight and the tidal flats of the Amrum Deep between the islands of Amrum and Föhr (Fig. 1). The salinity in the area is documented to range between 30 and $32 \mathrm{psu}$, and in general, mean water temperature is $14^{\circ} \mathrm{C}$ in summer and $5^{\circ} \mathrm{C}$ in winter. Further detailed information about size, hydrography, geology, sediments and biota of the List tidal basin are available from Reise (1985) and Gätje and Reise (1998).
Mussel beds have been sampled annually since 1998 in spring and autumn in the List tidal basin and during summer between the islands of Amrum and Föhr following standardised methods in the context of the blue mussel monitoring programme of the Trilateral Monitoring and Assessment Programme (TMAP) (TMAG 1997). Mussel bed size and coverage of mussels as well as their density and biomass are surveyed. Pacific oysters use these mussel beds as substrate. Oysters have been sampled annually since 2003 , at first with a $50 \times 50 \mathrm{~cm}$ frame. In response to increasing oyster densities, a reduced frame size $(25 \times 25 \mathrm{~cm})$ has been used since 2006 . The lengths of all oysters were measured to the nearest $1 \mathrm{~mm}$. The results presented here focus on four beds in the List tidal basin and sampling since 2003 (locations are shown in Fig. 1). Oyster mortality in the Amrum Deep is presented for three beds with continuous data since 2006 .
Fig. 1 Overview of the Wadden Sea and locations of mussel/oyster beds (black) in the List tidal basin (inset $A$ ) and Amrum Deep between the islands of Amrum and Föhr (inset B). Study sites are labelled. Dark grey islands and mainland, light grey tidal flats

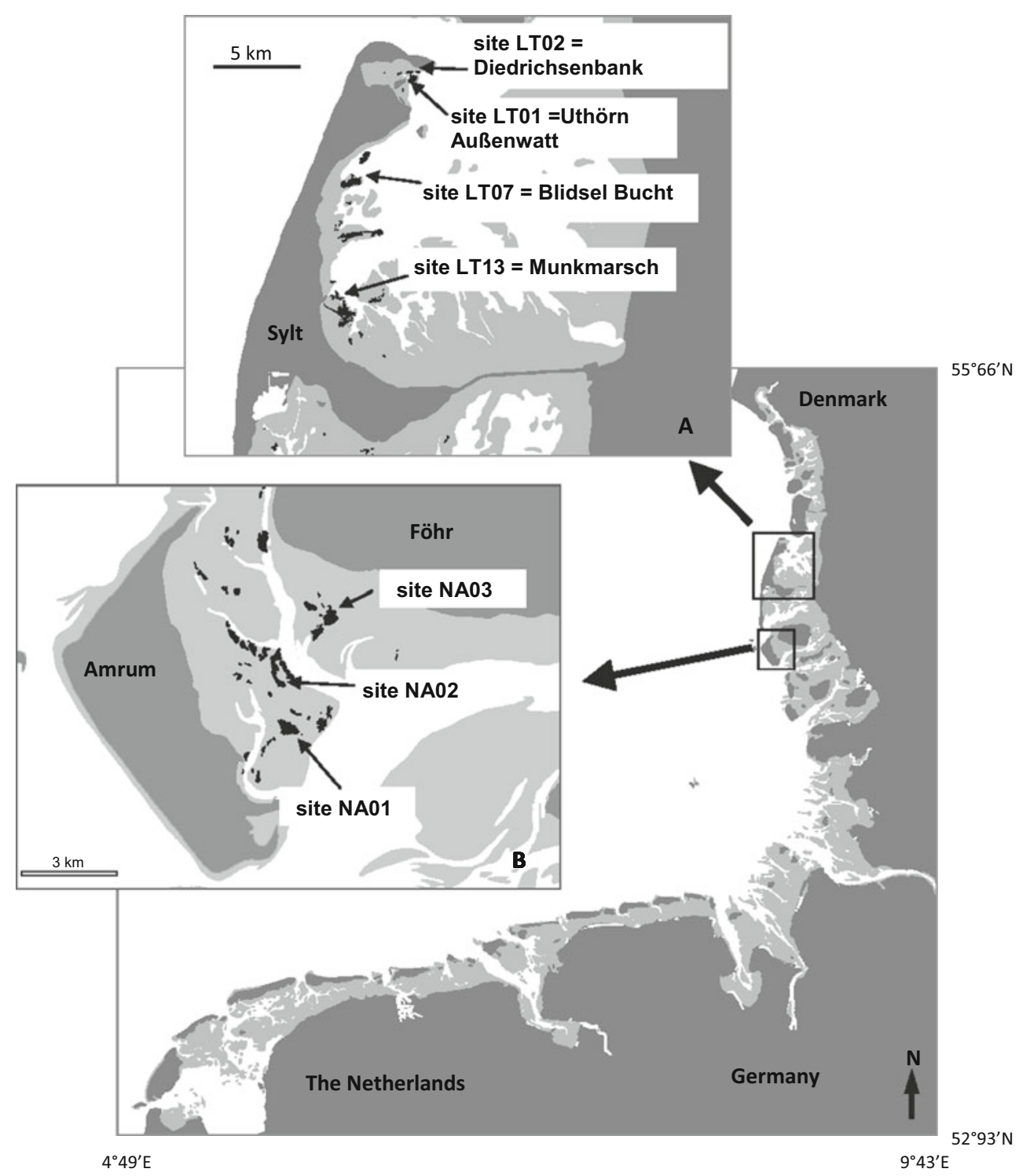


Winter mortality is calculated as losses in percentage of mean densities between sampling before and after the winter. For beds in the List tidal basin, it covers the period between sampling in autumn (generally September, exceptionally October) and spring (May, exceptionally April). Mortality calculations for beds in the Amrum Deep refer to sampling once in the summer months. To exclude spatfall and possibly high mortality of juvenile oysters as far as possible, oysters smaller than $3 \mathrm{~cm}$ are not considered. Significant differences in mean oyster densities between spring data and autumn data of the previous year in the Lister Deep and between summer data of consecutive years in the Amrum Deep were tested using the MannWhitney $U$ test. Differences were considered to be significant at $P<0.05$ (software WINSTAT 2009.1 by Robert K. Fitsch).

Sea surface temperatures (SST in ${ }^{\circ} \mathrm{C}$ ) at Amrum and List/Sylt were provided by the Federal Maritime and Hydrographic Agency of Germany (Loewe pers. comment). The air temperatures (lowest values measured $5 \mathrm{~cm}$
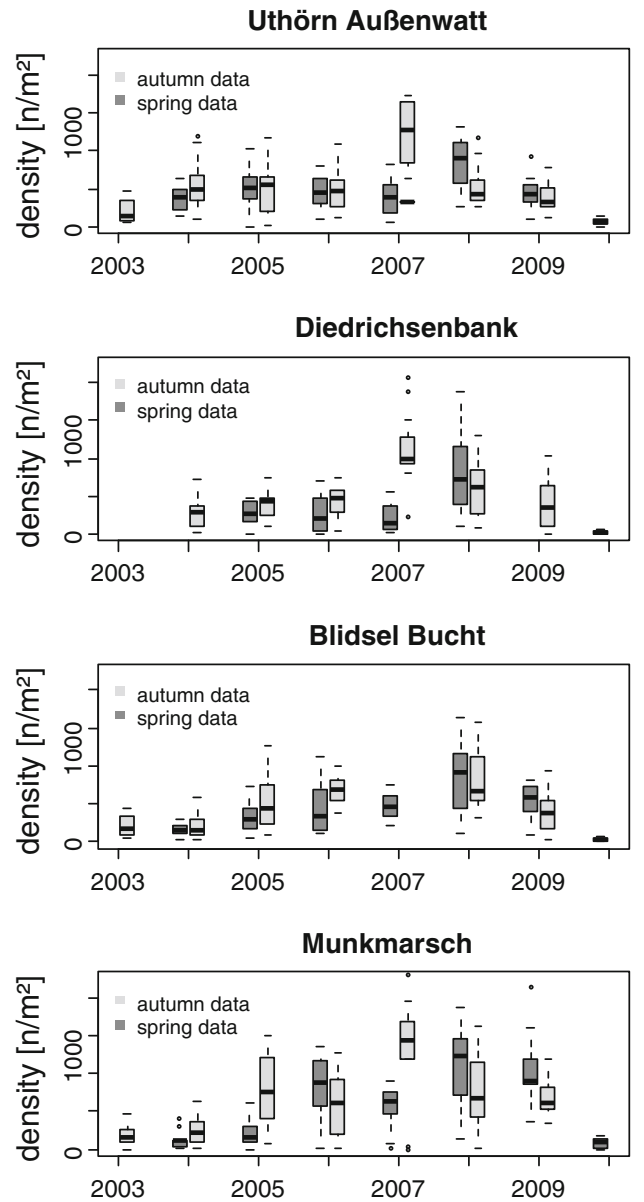

Fig. 2 Boxplots of Pacific oyster densities $\left(\mathrm{n} / \mathrm{m}^{2}\right)$ on four sites in the List tidal basin in the period September 2003 to May 2010 (left column) and on three sites between the islands of Amrum and Föhr (right column) in the period 2005-2010. Only oysters $>3 \mathrm{~cm}$ were above the ground) are measured by the German National Meteorological Service (DWD 2011).

\section{Results}

Since the first wild Pacific oyster was found in the List tidal basin in 1991 (Reise 1998), the stock spread out in the area and mean densities increased strongly until 2007. Due to an increasing oyster stock and a decreasing blue mussel stock, mussel beds in the List tidal basin have been dominated by oysters since 2004. Oysters reached the highest densities in 2007 after a spatfall in 2006, with mean values up to 1,368 ind./ $\mathrm{m}^{2}$ (oysters larger than $3 \mathrm{~cm}$, see Fig. 2). In the following years, no comparable spatfall occurred and densities declined.

Sampling these beds in May 2010 revealed significant mortality of oysters. An initial survey of bed LT02 (=Diedrichsenbank, Fig. 1) in March 2010, only few days after the ice cover had disappeared, revealed that about
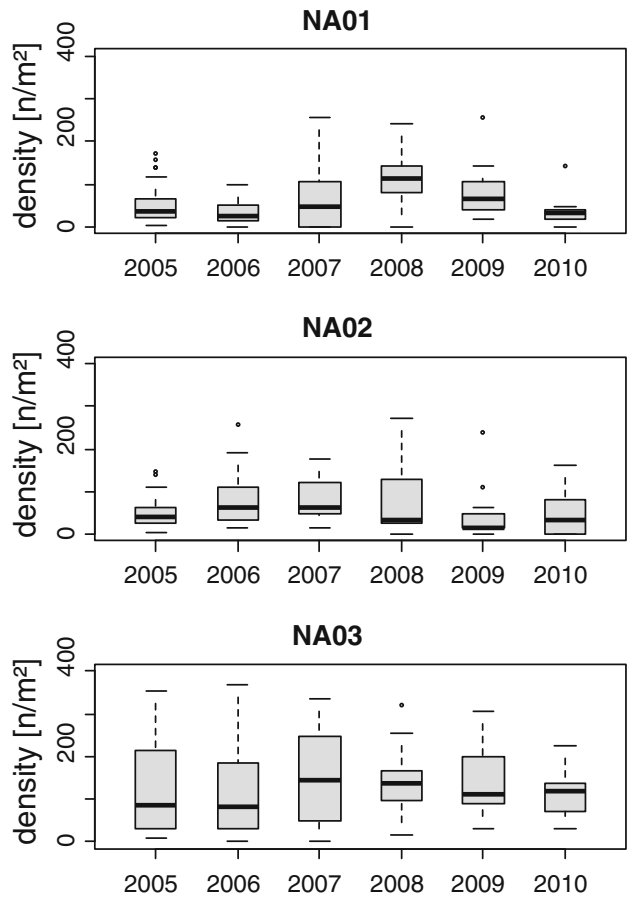

included. The thick horizontal line in the box is the median and the box is defined by the 25 th and 75 th percentiles. Points are outliers. Be aware of different $y$-axis scales 
Table 1 Results of significant differences (Mann-Whitney $U$ test) between oyster densities on mussel beds in the List tidal basin, based on the comparison of spring data with autumn data from the year before

\begin{tabular}{lllll}
\hline & LT01 & LT02 & LT07 \\
\hline Autumn 2003-spring 2004 & $\mathbf{0 . 0 4}$ & No data & 0.50 & 0.71 \\
Autumn 2004-spring 2005 & 0.90 & 0.72 & $\mathbf{0 . 0 3}$ & 0.76 \\
Autumn 2005-spring 2006 & 0.95 & 0.12 & 0.53 & 0.91 \\
Autumn 2006-spring 2007 & 0.40 & $\mathbf{0 . 0 4}$ & $\mathbf{0 . 0 2}$ & No data \\
Autumn 2007-spring 2008 & $\mathbf{0 . 0 2}$ & 0.14 & 0.06 & 0.30 \\
Autumn 2008-spring 2009 & 0.58 & No data & $\mathbf{0 . 0 0 0 1}$ & 0.23 \\
Autumn 2009-spring 2010 & $\mathbf{0 . 0 0 0 0 5}$ & $\mathbf{0 . 0 0 0 6}$ & $\mathbf{0 . 0 0 0 1}$ \\
\hline
\end{tabular}

Significant differences $(P<0.05)$ are indicated in bold text. For positive or negative changes in oyster densities compare with Fig. 4

$60 \%$ of the oysters were dead. Many oysters still contained flesh remains in various stages of decomposition. Sampling in May 2010 revealed even higher rates of loss. Oyster densities had decreased significantly on all beds between autumn 2009 and spring 2010 in the List tidal basin (Table 1). Mean densities in spring 2010 were about $90 \%$ lower compared to data from autumn 2009. The lengthfrequency distribution (Fig. 3, the data of site LT01 are shown, which are similar at the other sites) indicates that the winter mortality in 2009/2010 affected all size classes of oysters and hereby different cohorts.

Winter losses in previous years were much lower in the List tidal basin (Fig. 4). Before winter 2009/2010, highest mortality was noted during winter 2006/2007 with 32, 43 and $31 \%$ (sites LT01, 02 and 07). In the other years, the decrease in mean oyster densities ranged between $1 \%$ (Uthörn Außenwatt 2006) and 46\% (Diedrichsenbank 2007) and differed between sites and between years (Fig. 4).

In spring 2010, the dense oyster layers looked almost the same, in terms of size and shape, as they did in autumn 2009. Only sparsely populated flats lost oysters, which were not attached to others. In some places, oysters seemed to be mechanically influenced by ice shearing, as the tops of upright oyster shells were broken or oysters at the edge of the beds were smashed or removed (Fig. 5). However, most of the dead oysters were not visibly mechanically affected, as their shells were not damaged, and oyster beds were not removed by ice, which was the case for blue mussel beds in other parts of the Wadden Sea (own observations in May 2010).

In contrast, between the islands of Amrum and Föhr, oysters appeared some years later (about 1995), and densities are still much lower there compared to the List tidal basin. Here, highest values were reached in 2007 with 152 ind. $/ \mathrm{m}^{2}$ on site NA03 (oysters larger than $3 \mathrm{~cm}$, Fig. 2). After the winter 2009/2010, oyster densities only suffered significant reductions of $73 \%$ on site NA01, site NA03 lost up to $20 \%$ and densities on mussel bed NA02 even remained the same (Table 2). In previous years, reductions of mean oyster densities in the Amrum Deep ranged between 1\% (NA03 in 2009) and 44\% (NA02 in 2009) and again differed between sites and between years. Nevertheless, mortality in the Amrum Deep after the winter 2009/2010 was lower and did not show such a consistent picture as in the List tidal basin.

\section{Discussion}

Investigations of mussel beds in the List tidal basin in May 2010 revealed a high mortality of introduced Pacific oysters on four formerly densely populated beds. Densities decreased between autumn 2009 and spring 2010 by about 85 and $95 \%$. These values are the highest winter losses documented so far for this species in the North-Frisian Wadden Sea. In contrast, oyster densities on three beds in the area between the islands of Amrum and Föhr showed negative or even no trends. Oyster mortalities in Lower Saxony (Markert pers. comment) and in the Netherlands (Fey pers. comment) were not recognised to be raised after the winter 2009/2010.

In the period 2003-2009, density changes in the List tidal basin were variable and did not present such a clear picture of what was happening, as the events following the winter 2009/2010 did. All winters between 2003 and 2009 are described as very mild to moderate with at most some ice days (Schmelzer and Holfort 2009; DWD 2011), so that no effects of ice and low water and air temperatures occurred. An alternative explanation for oyster mortalities before 2009/2010 could possibly be a higher mortality, e.g. due to increasing intraspecific competition for space and food by growing oysters.

After a decade of mild winters the winter 2009/2010 was the first severe ice winter with a thick layer of ice covering the tidal flats. Ice winters can affect benthic communities of the Wadden Sea through low water- and air temperatures or mechanical disturbance such as ice shear or ice burden. 
Fig. 3 Length-frequency distribution of Pacific oysters on mussel bed Uthörn Außenwatt (LT01) in the period September 2003 to May 2010. Each plot contains the date of sampling and the total number of oysters $(n)$. The $x$-axis shows the length in $5 \mathrm{~mm}$ classes, and the $y$-axis shows the frequency (be aware of different scales)
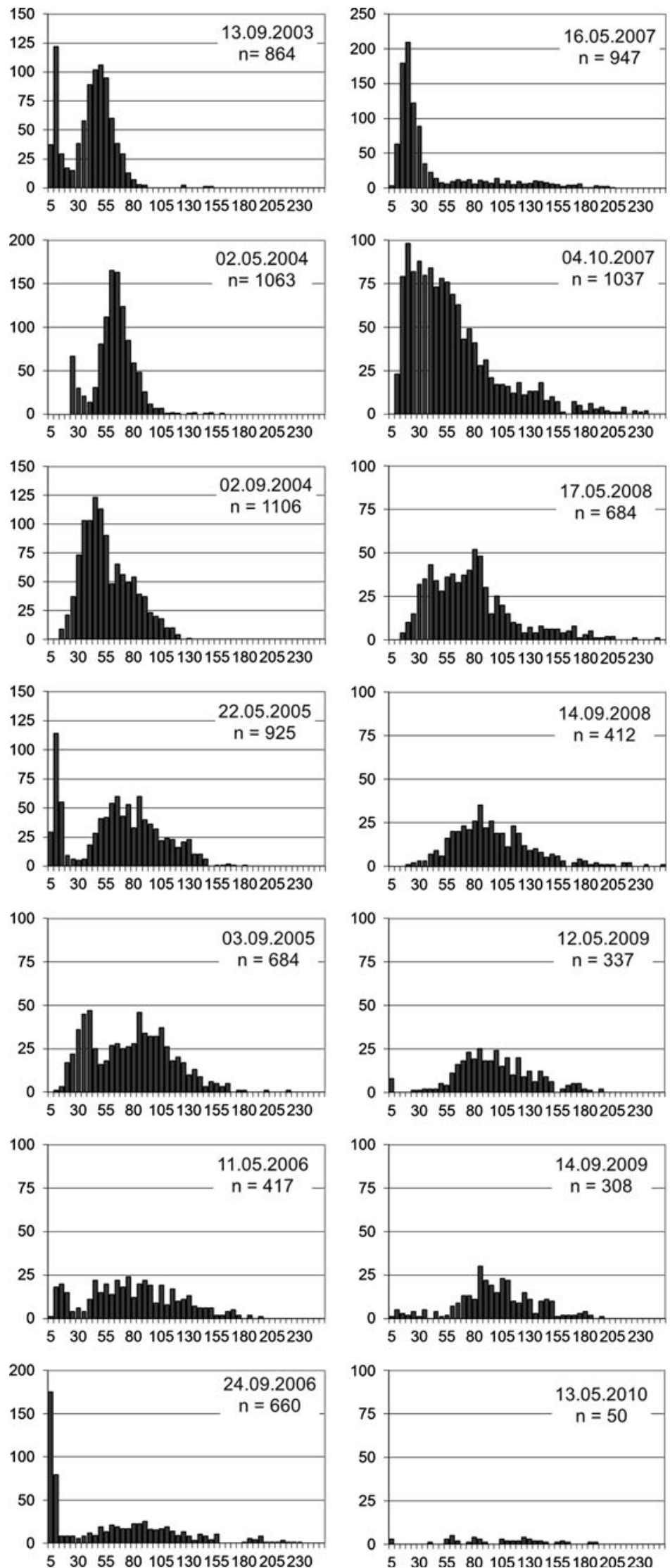

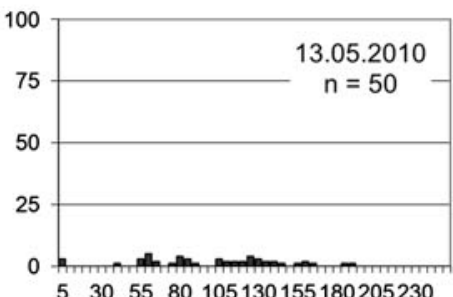



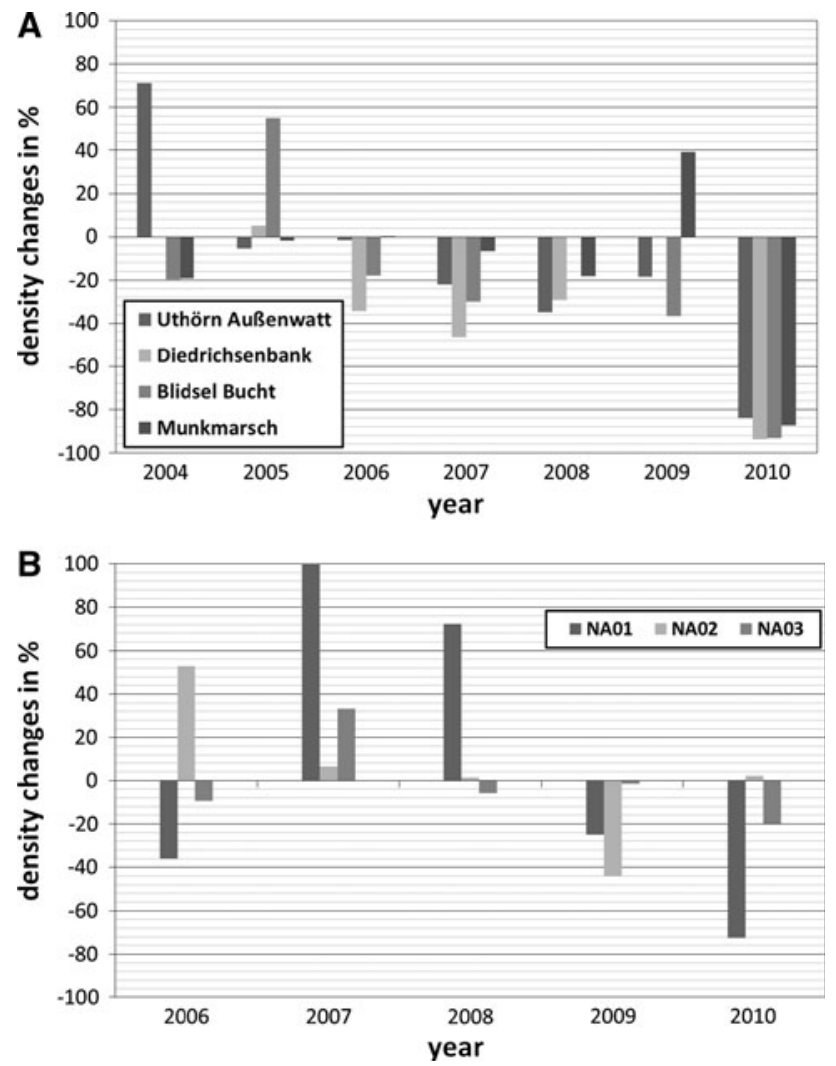

Fig. 4 Changes (in \%) of mean oyster densities per $\mathrm{m}^{2}$ (oysters $>3 \mathrm{~cm}$ ) on mussel beds in the List tidal basin (a) and between the islands of Amrum and Föhr (b). Data for mussel beds in the List tidal basin (a) refer to the period between autumn and spring of the following year, i.e. autumn 2003 in comparison to spring 2004. Data from the Amrum Deep (b) cover changes between annual summer samples

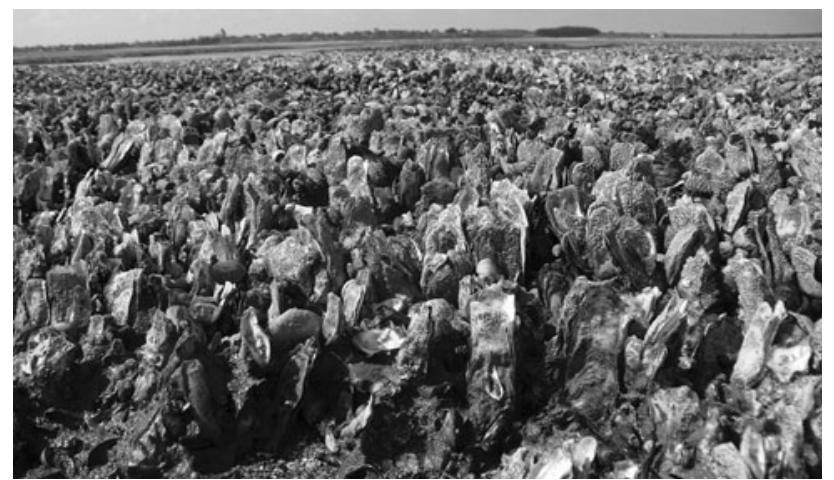

Fig. 5 An oyster bed in Munkmarsch, May 2010, with about $87 \%$ of dead oysters. Some oysters seem to show mechanical damage, as their tops are broken. Oysters on the edge of the bed in the foreground show extensive damage. However, most oyster shells in the bed are not obviously damaged

Observations following the ice winter of 2009/2010 indicated that Pacific oyster beds were less affected by ice shear (see Fig. 5). Mechanical effects appeared only on the
Table 2 Results of significant differences (Mann-Whitney $U$ test) between oyster densities on mussel beds between the islands of Amrum and Föhr (Amrum Deep), based on the comparison of annual summer (June-August) data

\begin{tabular}{llll}
\hline & NA01 & NA02 & NA03 \\
\hline 2005-2006 & 0.10 & 0.07 & 0.78 \\
$2006-2007$ & 0.39 & 0.43 & 0.35 \\
$2007-2008$ & $\mathbf{0 . 0 4 6}$ & 0.20 & 0.78 \\
$2008-2009$ & 0.18 & 0.19 & 0.86 \\
$2009-2010$ & $\mathbf{0 . 0 1}$ & 0.89 & 0.58 \\
\hline
\end{tabular}

Significant differences $(P<0.05)$ are indicated in bold text. For positive or negative changes in oyster densities compare with Fig. 4

edge of beds or on thinly populated areas with solitary oysters, which could be easily removed by ice. Effects on densely packed oyster beds were low. Oysters are cemented to each other and can form concretions some decimetres deep, which are inflexible and heavy. This physical arrangement probably prevents their translocation by ice. In the List tidal basin, ice was pushed together over the beds, and it was possibly partly frozen to the oysters. It formed thick and heavy layers of ice, which probably did not float completely during high tide.

During the winter 2009/2010, water temperature in the North-Frisian Wadden Sea dropped close to $0^{\circ} \mathrm{C}$ (BSH 2010b). The sea surface temperature (SST, Fig. 6) was below $2^{\circ} \mathrm{C}$ in both tidal basins from the 23 December 2009 and fluctuated afterwards between 0 and $2^{\circ} \mathrm{C}$ until the 16 March 2010 ( 83 days). It then increased up to $6^{\circ} \mathrm{C}$ until the end of March. Minimum air temperature (measured $5 \mathrm{~cm}$ above the ground) dropped in the same period to values mainly below $0^{\circ} \mathrm{C}$ and fluctuated between 2 and $-13^{\circ} \mathrm{C}$ (mean $-3.5^{\circ} \mathrm{C}$ ). Depending on the salinity of the water enclosed in their shells, oysters might survive longer periods of low air temperatures $(75 \%$ survival at $30 \mathrm{psu}$ at $-12^{\circ} \mathrm{C}$ air temperature, exposure for $6 \mathrm{~h}$ on 7 days, Wa Kang'eri 2005). Diederich (2006) investigated survival of juvenile oysters on intertidal beds in the List tidal basin and found that survival was high after the mild winter $2001 / 2002$ with more than $90 \%$, while it was low after the cold winter 2002/2003 (37 days with temperatures below freezing) with 25\%. However, Diederich (2006) also reported that adult oysters did not suffer from the cold winter. Reise (1998) documented that about $66 \%$ of the oysters in the List tidal basin (about 8 oysters $/ \mathrm{m}^{2}$ on blue mussel beds in 1995) survived the ice winter in 1995/1996 with more than 60 days with temperatures below freezing. Experiments with juvenile oysters revealed high mortalities ( $>95 \%$ ) after 3-7 weeks in water temperatures of $3^{\circ} \mathrm{C}$ (Child and Laing 1998). It thus remains unclear what the lower air and water temperature limits for Pacific Oysters in the Wadden Sea are and how long can they withstand such 
Fig. 6 Sea surface temperature (SST in ${ }^{\circ} \mathrm{C}$ ) measured at List/ Sylt and on Amrum between 01 December 2009 and 30 March 2010. The Federal Maritime and Hydrographic Agency (BSH) in Hamburg provided the data (Loewe pers. comment), which were measured by the German Maritime Search and Rescue Service (DGzRS). Additionally, the air temperature (minimum temperature measured $5 \mathrm{~cm}$ above the ground) in List/Sylt is presented for the same period (DWD 2011)

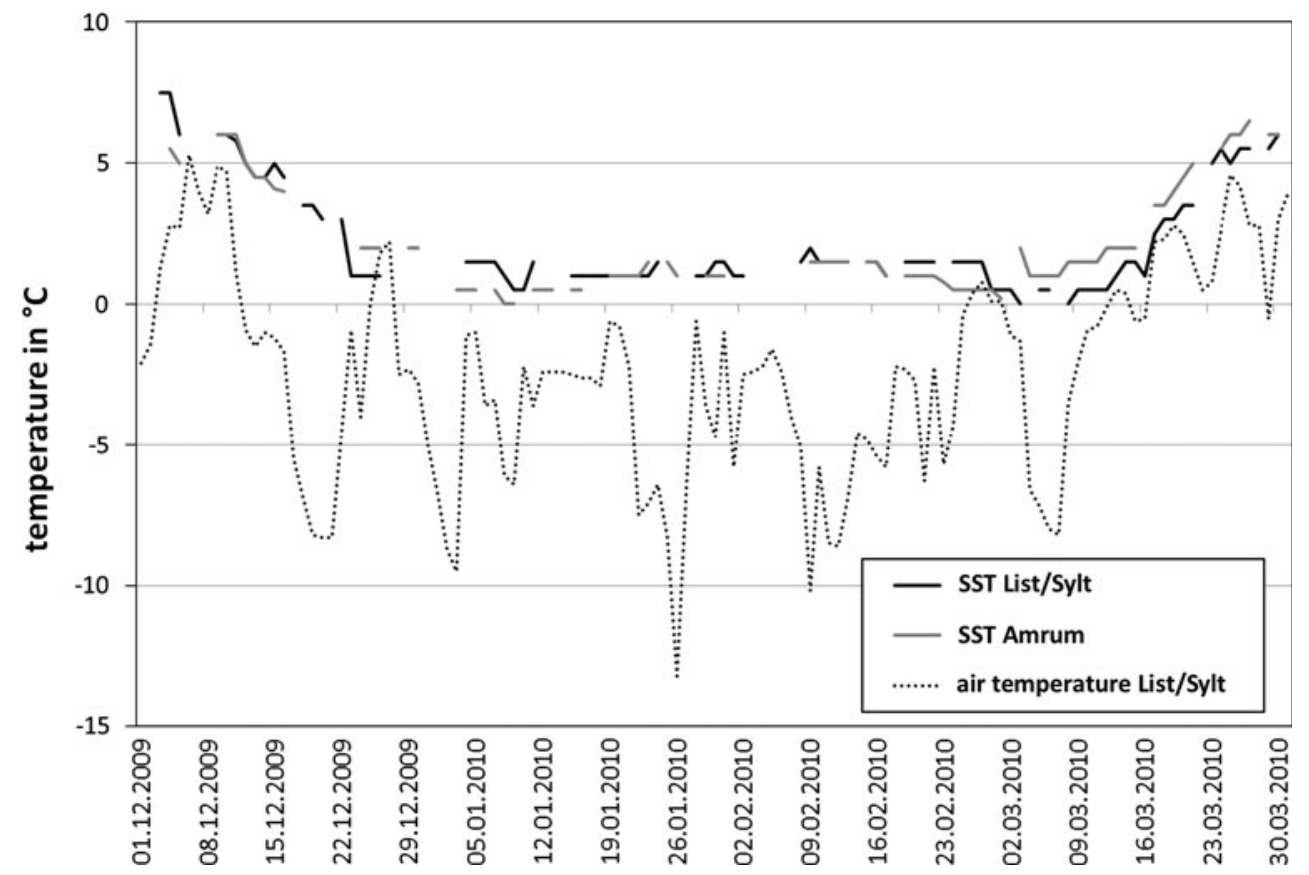

temperatures before succumbing to them. Pacific oysters stop filtration when the water temperature drops below $2^{\circ} \mathrm{C}$ (Averdung 2009). Low water- and air temperatures during the winter 2009/2010 (see above and Fig. 6) possibly led to a period of 11-12 weeks with low or no filtration. This was accompanied by the ice burden, which caused additional mechanical disturbance. It is possible that the combination of these factors exceeded the stress tolerance of Pacific oysters leading to the high mortality recorded (compare Newell 1989; Lacoste et al. 2002). Maybe, the mechanical stress was lower between the islands of Amrum and Föhr, or it only occurred locally on the site NA01.

Furthermore, oyster densities on former mussel beds were much higher in the List tidal basin than in the Amrum Deep. These high densities and the large oyster stock in the whole List tidal basin might have stressed the oysters to such an extent that they became more vulnerable to winter effects than the oysters in the southern Amrum Deep. To clarify the effects of low air and water temperature, mechanical disturbance by ice and intraspecific competition as well as their interactions on oyster survival in the Wadden Sea, more investigations and experimental tests are needed.

The native blue mussel population is strongly decreasing in the last decade in the Wadden Sea of Schleswig-Holstein (Nehls et al. 2009). In general, the decrease of blue mussel stocks is assumed to be induced by warm winters that led to the recruitment failure due to co-occurrence of mussel larvae and their predators, while warm summers support Pacific oyster recruitment, and oysters are considered to be tolerant to cold winters (Nehls et al. 2006). The winter 2009/2010 demonstrated that ice winters could lead to a significant reduction in the oyster stock in the Wadden Sea. In contrast, blue mussel recruitment seems to be facilitated by the reduced pressure from predators that occurs after such winters (Beukema and Dekker 2005; Strasser and Günther 2001). Thus, in theory, a severe winter seems to be able to depress the stock of the introduced Pacific oysters, while it might support the blue mussel recruitment and consecutive increase in the mussel stock.

However, we assume that the remaining oyster stock in the List tidal basin has the ability to compensate for the lost stock within a few warm summers. Due to the high mortality, the oyster population returned to a stock size comparable to some years ago, but with the same potential for recruitment that will be supported by presumably further warm summers to come (compare Diederich et al. 2005; Nehls et al. 2006). Thus, ice winters may strongly affect interannual variation in oyster densities, but long-term effects on oyster populations or their persistence in the Wadden Sea are not expected by erratic severe winters.

Acknowledgments Our work is supported by the Regional Office of the Wadden Sea National Park of Schleswig-Holstein. Thanks to numerous people for field assistance and sample proceeding. We are grateful to C. Buschbaum, D. Fleet and two anonymous reviewers for valuable comments on the manuscript. And we are grateful to P. Loewe (BSH Hamburg) who provided straightforward the SST-data.

\section{References}

Averdung M (2009) Filtrationsraten der heimischen Miesmuschel Mytilus edulis und der eingewanderten Auster Crassostrea gigas 
bei winterlichen Temperaturen. Diploma thesis, Universität Hamburg

Beukema JJ (1992) Expected changes in the Wadden Sea benthos in a warmer world: lessons from periods with mild winters. Neth J Sea Res 30:73-79

Beukema JJ, Dekker R (2005) Decline of recruitment success in cockles and other bivalves in the Wadden Sea: possible role of climate change, predation on postlarvae and fisheries. Mar Ecol Prog Ser 287:149-167

BSH (2010a) http://www.bsh.de/de/Meeresdaten/Beobachtungen/Eis/ nordsee.jsp

BSH (2010b) http://www.bsh.de/de/Meeresdaten/Beobachtungen/ MURSYS-Umweltreportsystem/Mursys_031/seiten/note1_01. jsp\#februar2010

Carrasco MF, Barón P (2010) Analysis of the potential geographic range of the Pacific oyster Crassostrea gigas (Thunberg, 1793) based on surface seawater temperature satellite data and climate charts: the coast of South America as a study case. Biol Invasions 12:2597-2607

Child AR, Laing I (1998) Comparative low temperature tolerance of small juvenile European, Ostrea edulis L., and Pacific oysters, Crassostrea gigas Thunberg. Aquacult Res 29:103-113

Diederich S (2006) High survival and growth rates of introduced Pacific oysters may cause restrictions on habitat use by native mussels in the Wadden Sea. J Exp Mar Biol Ecol 328:211-227

Diederich S, Nehls G, van Beusekom JEE, Reise K (2005) Introduced Pacific oysters (Crassostrea gigas) in the northern Wadden Sea: invasion accelerated by warm summers? Helgol Mar Res 59:97-106

DWD (2011) Frei zugängliche Klimadaten. Download: http://www. dwd.de/bvbw/appmanager/bvbw/dwdwwwDesktop?_nfpb= true\&_pageLabel=_dwdwww_menu2_leistungen_a-z_freieme tinfos\&T115202758871200642573928gsbDocumentPath=Navi gation\%2FOeffentlichkeit\%2FKlima_Umwelt\%2FKlimadaten zentren $\% 2$ FNKDZ\%2Fkldaten_akt $\% 2$ Fausgabe_tageswerte_node.html\%3F_nnn\%3Dtrue

Gätje C, Reise K (1998) Ökosystem Wattenmeer, Austausch-, Transport- und Stoffumwandlungsprozesse. Springer, Berlin
Lacoste A, Malham SK, Gélébart F, Cueff A, Poulet SA (2002) Stress-induced immune changes in the oyster Crassostrea gigas. Dev Comp Immunol 26:1-9. doi:10.1016/S0145-305X(01) 00067-2

Nehls G, Büttger H (2007) Spread of the Pacific Oyster Crassostrea gigas in the Wadden Sea. Causes and consequences of a successful invasion. HARBASINS report. CWSS, Wilhelmshaven

Nehls G, Diederich S, Thieltges DW (2006) Wadden Sea mussel beds invaded by oysters and slipper limpets: competition or climate control? Helgol Mar Res 60:135-143

Nehls G, Witte S, Büttger H, Dankers N, Jansen J, Millat G, Herlyn M, Markert A, Sand Kristensen S, Ruth M, Buschbaum C, Wehrmann A (2009) Beds of blue mussels and Pacific oysters. Thematic report no. 11. In: Marencic H, de Vlas J (eds) Quality status report 2009. Wadden Sea ecosystem no. 25, Common Wadden Sea Secretariat, Trilateral Monitoring and Assessment Group, Wilhelmshaven, Germany

Newell RIE (1989) Species profiles: life histories and environmental requirements of coastal fishes and invertebrates (North and Mid-Atlantic)_Blue mussel. US Fish and Wildlife Service Biological report 82(11. 102). US Army Corps of Engineers, TR El-82-4, 25 pp

Reise K (1985) Tidal flat ecology. Springer, Berlin

Reise K (1998) Pacific oysters invade mussel beds in European Wadden Sea. Senckenb Marit 28:167-175

Schmelzer T, Holfort J (2009) Eiswinter 2004/05 bis 2008/09 an den deutschen Nord- und Ostseeküsten —ice winters 2004/05 to 2008/09 on the German North and Baltic Sea Coasts. Berichte des Bundesamtes für Seeschifffahrt und Hydrographie Nr. 46/2009, 77 pp

Strasser M, Günther CP (2001) Larval supply of predator and prey: temporal mismatch between crabs and bivalves after a severe winter in the Wadden Sea. J Sea Res 46:57-67

Trilateral Monitoring and Assessment Group (1997) TMAP manual. The Trilateral Monitoring and Assessment program (TMAP), Common Wadden Sea Secretariat, Wilhelmshaven

Wa Kang'eri AK (2005) Winter mortality and freeze tolerance in Pacific oysters Crassostrea gigas (Thunberg). MSc thesis, University of Groningen, Department of Marine Biology, $53 \mathrm{pp}$ 